Article

\title{
Doctors’ Vision Regarding Undergraduate Medical Curriculum of Bangladesh
}

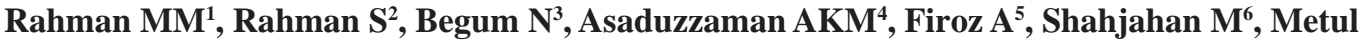 \\ MS $^{7}$, Nabi CMG $^{8}$
}

This study was done to identify the lacking in conducting MBBS course-curriculum of Bangladesh. For this purpose a descriptive survey was done among 30 MBBS doctors (Passed within 10 years) of Faridpur district. No internship doctors were included. Self-administered unstructured questionnaire was supplied to them and qualitative analysis of data was done. Majority doctors dissatisfied with (i) Gaining knowledge and skill (ii) Environment of medical colleges (iii) Teaching method (iv) Less MCQ (v) Existing viva-voce (vi) Library facilities (vi) Less clinical symposium.

Key Words: Under Graduate; Medical Education; Curriculum; Doctor; Bangladesh

J Bangladesh Soc Physiol. 2007 Dec;(2): 54-59. For author affiliations, see end of text.

http://www.banglajol.info/index.php/JBSP

\section{Introduction}

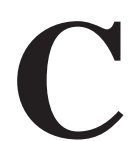

avemen and women must have performed some sort of medical treatment when they became ill. Unfortunately there was no alphabet to record the medical practices. Earliest doctors and artists painted symbols on cave walls which included images of how they treated illness. We can surmise that treatment and prevention were probably based on religious and superstitious beliefs. Evidence of ancient medical practices have been found in Egypt, India, China and Japan around 460 B.C. Hippocrates wrote down all his medical knowledge. Other scientists were also added. ${ }^{1}$

History of modern medicine is filled with scientific break through and lifesaving discoveries. ${ }^{1}$ Medical students learning objectives are: (i) respect for privacy and dignity of patients (ii) knowledgeable (iii) skillful (iv) knowledge of epidemiology. ${ }^{2}$ Medical education, training, clinical experience, doctors' personal values and beliefs had the greatest influence on medical practice. ${ }^{3}$

Physician conduct (art and technical aspects of quality) is one of the satisfaction of clients. ${ }^{4}$ Capability of doctors' understanding of clients problems can satisfy them. ${ }^{5}$ Lack of confidence in doctor's competence and unfavorable attitudes towards doctor's personal qualities may lead to dissatisfaction with change of doctors. ${ }^{6}$ Majority of respondents expressed satisfaction with most aspects of care, except for doctors' availability in an emergency, preventive teaching and aspects of communication. ${ }^{7}$ Physicians behave in a manner that facilitates the patient to express himself, speak openly and ask questions. ${ }^{8}$ Patients become satisfied if they got optimum time for consultation with doctor. ${ }^{9}$

Patients expect to have a comfortable and worm interaction with a physician. ${ }^{10-13}$ When expectation towards doctors were not fulfilled, patients were less satisfied less likely to comply 
with their medical regimen, and return visit. ${ }^{14-}$

${ }^{21}$ Psychological impact of the physician-patient relationship may decrease anxiety, increase feelings of well-being and promote recovery from illness. ${ }^{22}$ Patient choose personal qualities and professional competence of physicians. ${ }^{23}$ Three dimensions of patient's satisfaction studied were doctor's conduct, convenience and general satisfaction. ${ }^{24}$

Medical education program for rural development which improves medical students community orientation and as well as research skill. ${ }^{25}$ Faculty development may be done through symposium consisting of clinical and research information presented by recognized experts. ${ }^{26}$ Major complaints against doctors of emergency department were poor communication, diagnosis and treatment. ${ }^{27}$ Quality education result from excellent teaching which depends on qualified teachers who also add knowledge through research. ${ }^{28}$

From the above review it may be concluded that patient's satisfaction depends upon (i) Proper knowledge (ii) Skill (iii) Behavior and (iv) Communication. But in reality patients are not satisfied with doctors.

Whether these are learned by MBBS doctors through their existing course-curriculum or not in Bangladesh. So this study was done among MBBS doctors to know their views regarding MBBS course-curriculum of Bangladesh.

\section{Methods}

A descriptive survey was done among doctors of Faridpur district. Opinion was collected by preparing questionnaire (combination of both unstructured and structured) and was selfadministered. For this purpose total 30 doctors were selected as sample. Among them 20 doctors were selected from out-door of Faridpur Medical College hospital and one Thana Health Complex.

Another 10 doctors were selected from general physicians (Non-Government Private
Practitioners) of Faridpur Town and one Thana. All were MBBS doctors and became doctor within 10 years. No internship doctors were included. Data were collected and qualitative analysis was done.

\section{Results}

Self-administered interview were done among MBBS doctors working in Faridpur District (includes both general physicians and outdoor medical officers) More than $50 \%$ doctors were not satisfied with their gaining knowledge and skill during MBBS course (Table $-\mathrm{I}$ ) as because medical education was not updated in Bangladesh; less practical oriented; teachers were not guiding properly in both academic and training period; lack of facilities and equipment.

Table - I: Shows the doctors' opinion regarding their gaining knowledge and skill during MBBS course.

\begin{tabular}{lcc}
\hline Parameter & Frequency & Percentage \\
\hline Overall knowledge & 2 & 6.7 \\
Skill & 1 & 3.3 \\
Both knowledge and skill & 13 & 43.34 \\
Non responding & 14 & 46.66 \\
Total = & 30 & $100 \%$ \\
\hline
\end{tabular}

Knowledge can be improved (as suggested by different doctors) by changing the teachers' mentality, appointment of skilled teachers, improving co-operation between teachers and students, updating of medical course-curriculum, spending of sufficient time for study, fulfilling of medical colleges and hospitals with modern medical equipment (may seek foreign aids for this purpose), increasing manpower and improving environment of the institute (through prohibiting of student politics). Doctors also thought that all doctors should be academic, acquiring post-graduate degree, weekly arrangement of clinical session and decentralization of higher degrees. 
Article

Skill-ness can be developed through training. It is necessary to arrange proper internship training and should be 2 years of duration. Other training for doctors also will be effective.

Proper training includes exposure to specific field, enriched with undated knowledge under supervision of subject specialist and need have had work by participants (As suggested by respondents). Also require sufficient facilities for quality treatment.

Fifty percent doctors told that their teachers in medical colleges were not up to the optimum level for effective teaching. Lacking in them were as follows: lack of sincerity, deficiency in recent knowledge in medical science, poor in English expression, lack of commitment to serve the country, lack of specialized (Diploma not included) teachers, teaching method was not so attractive and not practical oriented.

Seventy percent doctors responded that environment of medical colleges (From where they graduated) were not in favor of learning process due to student politics, lack of accommodation in hostel, shortage of educational equipment and qualified teachers. Sixty percent doctors rejected existing teaching method (Table - II) as because it was poor, curriculum was less

Table -II: Shows the opinion of doctors' about teaching method in MBBS course.

\begin{tabular}{lcc}
\hline $\begin{array}{l}\text { Existing teaching } \\
\text { method is sufficient }\end{array}$ & Frequency & Percentage \\
\hline 1 1. Yes & 12 & 40 \\
2. No & 18 & 60 \\
\hline Total $=$ & 30 & 100 \\
\hline
\end{tabular}

applied oriented, professors expended less time for clinical classes, less MCQ questions (50\% should be MCQ type) in MBBS exam, defective viva-voce (Judgement is not so accurate), poor
Under Graduate Medical Curriculum of Bangladesh

library facilities, lack of clinical symposium and lack of close relationship between teachers and students.

Majority doctors (70\%) responded that behavioral science which was taught in MBBS course that was not sufficient. This subject was neglected and should be included as a special paper with more period of time in MBBS curriculum in the $3^{\text {rd }}$ and $4^{\text {th }}$ years.

Doctors (93.3\%) were not engaged in research work due absence of facilities, lack of fund, time, knowledge and monitory benefit. Few doctors (6.7\%) were engaged in research but felt problem regarding fund and co-operation of others (related personnel).

Most doctors (73.3\%) agreed for adding preliminary research idea is MBBS course, so that student can know research procedure which will be helpful for future career and to solve the different problems.

Different doctors thought regarding faculty development in different ways. Those were as follows: there were need of appointment of increase no. of quality teachers and they should be committed to their students; improvement needed in the teaching methodology with recent knowledge (so that students get interest in learning) and all teachers must share equal responsibility with each other; examination must be on time; all sorts of supports given by authority for maintenance of academic environment; medical equipment should be available; proper training of the teachers; to develop good relationship between teachers and students and students politics must be prohibited.

Majority doctors (93.3\%) learned treatment of emergency problem but among them $70 \%$ doctors were not satisfied with the acquired knowledge and skill (Table - III, IV).

J Bangladesh Soc Physiol. 2007 Dec;(2): 54-59. 
Table-III: Shows the opinion on learned emergency problem.

Learned management Frequency Percentage of emergency problem

\begin{tabular}{llcc}
\hline 1. Yes & 28 & 93.3 \\
2. No & 02 & 6.7 \\
\hline Total $=$ & 30 & 100 \\
\hline
\end{tabular}

Table-IV: Shows the effectiveness of learned emergency treatment.

Learned emergency Frequency Percentage problems are sufficient

to fulfill the demand

\begin{tabular}{llc}
\hline 1. Yes & 08 & 26.7 \\
2. No & 21 & 70 \\
3. Non-responding & 01 & 3.3 \\
\hline Total $=$ & 30 & 100 \\
\hline
\end{tabular}

Suggestion given by doctors were (for improving knowledge and skill regarding emergency treatment) as follows: all sorts of emergency medial equipment will be available; need better communication; need to establish hospital in every village; need special training for the doctors; nurses and other staffs; skill-ness require in the doctor, nurses and other assistants; easy available of emergency drugs; blood bank should be established and ambulance should be available.

\section{Discussion}

Doctors should be cordial, attentive and to give importance to the patients. But in reality not so happened. Clients were not satisfied with doctors' service. There is need to change the doctors' attitude. Study on Behavioral science and doctors' accountability may change the attitude. $^{24,29}$

Teachers of medical colleges were not enriched with recent knowledge, lack of sincerity, poor
English expression, and lack of specialized teachers and teaching method was not so attractive and not practical oriented.

For developing knowledgeable and skilled doctors there are need to updating coursecurriculum; teaching must be enriched with recent knowledge and more practical oriented; Medical colleges would be enriched with modern equipment (including emergency set) and facilities (Both for teachers and students); appointment of qualified and skilled teachers; proper training must be needed (including special training on emergency management); Professors should give more time with the students;29, 30 improvement of environment of the institute ${ }^{29}$ (Proper hostel accommodation, prohibition of student politics etc.) and proper guidance of teacher. $^{31}$

For faculty development there were need of appointment of increase no. of quality and skilled teachers, improved teaching method with recent knowledge, examination must be on time, development of academic environment, well equipped with modern instruments (educational, investigative and treatment), proper training to teacher on teaching method (including degree) and optimum manpower 28,32

Research is also important for faculty development $^{26}$ and as well as development of medical science as a whole. ${ }^{1}$ But few doctors were involve in research due to less time (doctors were overloaded with works), lack of fund, lack of knowledge and less monitory benefit. ${ }^{33}$

From above review it may be concluded that there is need to change course curriculum of MBBS degree. More emphasis will be given to the Behavioral science and it may be introduced as a separate subject of $3^{\text {rd }}$ and $4^{\text {th }}$ years. There may be introduction of subject of management and administration (related to health service). Rearrangement of written and viva-voce examination so that proper judgement is possible. Preliminary idea regarding research may be introduce in the MBBS course. 


\section{Article}

Besides that other measures needed to arrange are as follows:

Increase fund in health sector, create good environment for the working doctors,

To increase monitory benefit in research work, decrease the workload of doctor so that they can involve in research, to cerate awareness among doctors and other peoples regarding research. Further in-depth of study is requiring to sort-out deficiency in MBBS course-curriculum for producing qualified doctors.

\section{Acknowledgement:}

Authors thank to World Health Organization for financial support.

\section{Author Affiliations}

1. * Dr Md Mohidur Rahman, Associate Professor of Physiology, Faridpur Medical College, Faridpur, Bangladesh

2. Professor Dr Shafiqur Rahman, Ex-director, BMRC, Bangladesh

3. Professor Dr Noorzahan Begum, Chairman, Department of Physiology, BSMMU, Shahbag, Dhaka, Bangladesh

4. Dr AKM Asaduzzaman, Assistant Professor, CME, Mohakhali, Dhaka - 1212, Bangladesh

5. Ahmed Firoz, Assistant Professor of Anatomy National Medical College, Dhaka, Bangladesh

6. Md Shahjahan, Scientific Officer, Bangladesh Medical Research Council, Mohakhali, Dhaka - 1212, Bangladesh

7. Dr Morshida Sikder Metul, Medical officer, Islami Bank Community Hospital, Faridpur, Bangladesh

8. Chawdhury Md Golam Nabi, Chairman, Rotaract Interact Committee, Rotary Club, Faridpur, Bangladesh

* For correspondence

\section{References}

1. Fraustino IR. What Medical Office Assistants do. A brief history of Medicine. Introduction to Medical office Assisting. ICS intangibles holding company. 1994;1:27-28.

2. Learning objectives for medical student educationguidelines for medical schools: report of the medical school objectives project. Acad. Med. Jan, 1999; 74(1): 13-8.

3. Henley L, Benatar SR, Robertson BA and Ensink K. informed consent-a survey of doctors' practices in South Africa. SAMJ. December, 1995; 85(12): 12731278.
Under Graduate Medical Curriculum of Bangladesh

4. Dolye BJ and ware JE Jr. Physician conduct and other factors that affect consumer satisfaction with medical care. J Medical Educ. Oct, 1977; 52 (10):793-801.

5. Ahmed MB and Koltuv M. Evaluation of an inpatient service by consumer feedback. Aust. N.Z.J. Psychiatry. Sept., 1976; 10(3)263-8.

6. Kasteler J, Kane RL, Oslen DM and Thetford C. Issues underlying prevalence of “doctor-shopping” behavior. J Health Soc. Behav. Dec, 1976; 17(4):329-39.

7. Patric DL, Scrivens E and Charlton JR. Disability and patient satisfaction with medical care. Med Care. Nov, 1983; 21(11): 1062-75.

8. Stewart M A. what is a successful doctor-patient interview? A study of interactions and outcomes. Soc Sci Med. 1984; 19(2): 167-75.

9. Ley P. Doctor-Patient communication: Some quantitative estimates of the role of cognitive factors in non-compliance, J. Hypertens. Suppl Apr, 1985;3(1): 351-5.

10. Deisher RW, Engel WC, Spielholz R and Standfast SJ. Mother's opinions of their pediatric care. Pediatrics. 1965; 35:82-90.

11. Fisher AW. Patients' evaluation of out patient medical care. J Med Educ. 1971; 46: 238-244.

12. Koos EL. "Metropolis"- what city people think of their medical services. Am J Pub Health. 1955; 45:15511557.

13. Reader G G, Pratt $L$ and Mudd MC. What patients expect from their doctors. Med Hosp. 1957; 89(1): 88-94.

14. Becker M H and Maiman LA. Sociobehavioral determinants of compliance with health and medical care recommendations. Med. Care.1975; 13:10-24.

15. Davis M. variations in patient's compliance with doctor's advice: An empirical analysis of patterns of communication. Am J. Pub Health. 1968; 58: 274-288.

16. Francis V, Korsch BN and Morris MJ. Gaps in doctorpatient communication II. Patients' response to medical advice. New Engl J Med. 1969; 280: 535-540.

17. Hayes-Bautisia DE. Modifying the treatment: Patient control and medical care. Soc Sci Med. 1976; 10: 233-238.

18. Kincey J. Bradshaw P and Ley P. patients' satisfaction and reported acceptance of advice in general practice. J. R, Coll, Gen. Practitioners. 1975;25:558-566.

19. Kirscht J P. Communication between patients and physicians. Ann Intern Med. 1977; 86.

J Bangladesh Soc Physiol. 2007 Dec;(2): 54-59. 
20. Stimson GV. obeying doctors' orders: A view from the other side. Soc Sci Med. 1974; 8:97-104.

21. Waitzkin M and Stoeckle JD. The communication of information about illness: clinical, sociological and methodological considerations. Adv Psychosom Med. 1972;8:180-215.

22. Egbert L D, Battit G E, Welch C E and Bartlett M K. Reduction of Post-operative pain by encouragement and instruction of patients. New Engl J Med. 1964; 270: 825-827.

23. Hulka B S, Zyzanski S J, Cassel J C and Thompson S J. Satisfaction with medical care in a low income population. J Chron Dis. 1971; 24: 661-673.

24. Linder- Pelz S. Social psychological determinants of patient satisfaction: a test of five hypotheses. Soc Sci Med. 1982;16:583-589.

25. Hamad B. Interdisciplinary field training research and rural development programme. Med Educ. Mar, 1982; 16(2): 105-7.

26. Wallace R K, Ford A B and Wallace RW. Geriatric medical education: A project in faculty development. J Am. Geriatr Soc. Feb, 1983; 31(2): 106-8.
27. Kadzombe E A and Coals J. complaints against doctors in an accident and emergency department a 10 year analysis. Arch Emerg. Med Jun, 1992; 9(2): 134-42.

28. Ramsey Jr. CN and Hitchcock MA. A state way Model for faculty development in family medicine. The Journal of family Practice. 1980; 11(3):421-426.

29. Levine DM, Barsky AJ, fox RC, Freidin RB, Williams SR and Wysong JA. Trends in medical education research: Past, present and future. Journal of Medical education. Feb, 1974; 49:129-136.

30. Cutting W A M. Health team leadership: the doctor's role. Trop Geogr Med. 1974;26:216-222.

31. Bennett MJ and Ewan CE. Medical teaching-help or hindrance? Med Educ. Mar, 1982; 16(2): 63-7.

32. Bland CJ and Froberg DG. A systematic approach to faculty development for family practice faculty. The journal of family practice. 1982; 14(3): 537-543.

33. Parkerson GR Jr., Barr DM, Bass M, Bland CJ, Froom J, Geyman J P, Hames C, Mc whinne1, Medalie, JH, Moore AS, Perkoff G, Rosenblatt R, Seifert MH Jr., Spitzer W, Williams T and Wood M. Meeting the challenge of research in family medicine: report of the study group on family medicine research. J Fam Pract. Jan., 1982; 14(1): 105-113. 